\title{
LITHUANIA TRANSPORT SERVICE PROVIDERS' POSITION IN THE BALTIC SEA REGION TRANSPORT MARKET
}

\author{
Darius Bazaras ${ }^{1}$, Ramūnas Palšaitis ${ }^{2}$ \\ Transport Management Department, Vilnius Gediminas Technical University \\ Plytinès 27, Vilnius LT-10105, Lithuania \\ ${ }^{I}$ Ph.: +370 5 2370635.Fax: (+370 5) 2745059.E-mail:dbazaras@vgtu.lt \\ ${ }^{2}$ Ph.: +370 5 2744776.Fax: (+370 5) 2745059.E-mail:trvadyba@vgtu.lt
}

\begin{abstract}
Assessment of Lithuanian road transport service providers' position in the Baltic Sea region identified, that the Lithuanian road transportation market has the tendency of recovery after the economic and financial crisis. Lithuanian transport companies operating in the BSR and EU market are small - average $7 \mathrm{HGV}$ in the company but they remain competitive in the area of quality service offered. It is defined significant renewal of HGVs fleet - more than thirty percent's of vehicles have EURO-4 and EURO-5. Big transport companies are extending their service package and in the parallel with the transportation are proposing to the customers' logistics service package or dedicated services.
\end{abstract}

Keywords: transport, service quality, security

\section{Introduction}

The road freight market has been under a serious reconstruction. The strong economic growth during the first years of the $21^{\text {st }}$ century together with the expansion of the European Union attracted a number of new entrants to the market. The changes, which are taking place in the international transport services market demand not only the modernization of the current infrastructure, by releasing intended development projects, but also the application of modern transportation technologies. The Lithuanian geopolitical state and well-developed transportation infrastructure provide a possibility not to remain in the background of current changes in the transit services market, but to act as a mediator in the expansion of trade connections of the most important transportation corridors between East and West. The objective of this paper is to explore how the prevailing market conditions in the Baltic Sea Region have affected Lithuania transport service providers.

\section{Design/Methodology/Approach}

In this paper is summarized data from interviews conducted in the Lithuania between in the beginning of 2011 as part of an EU funded project "Connecting Authorities for Safer Heavy Goods Traffic in the Baltic Sea Region" (C.A.S.H.). The interviews in early 2011 were conducted with Lithuanian public authorities and companies engaged in border-crossing road transport.

The aim of the interviews in Lithuania was to provide an understanding of how the prevailing market conditions in the Baltic Sea Region may have affected:

A. The market for international road freight transport in the BSR;

B. Traffic safety of border-crossing freight transport and safety enforcement;

C. Traffic safety and safety culture in border-crossing freight transport;

D. Security of drivers, trucks and cargo in the BSR.

The interviews aimed to provide general understanding of possible differences in the enforcement of HGV traffic and the compliance of regulations particularly:

- during the past 4-5 years (years 2005-2006);

- by the end of 2010 ("current situation"). 


\section{Market for International Lithuania HGV Road Freight Transport}

According to general assessments, situation by the beginning of 2011, compared to 2005-2006, didn't change. The absence of changes in Lithuania could be explained as follows: the economic development curves during the period under analysis must have been similar (consequently, transport market trends were more or less the same): the years 2005-2006 were the period of "growth"; in order to meet the growing demand all companies tried to supply themselves with capacities (from own or borrowed funds); at the beginning of 2011 the signs of "recovery" emerged and determined recovery (increase) of capacities.

According to the assessment of general availability of the international HGV road transport capacity from the shipper's perspective in Lithuania in 2005 and at the beginning of 2011, in 2011 the shipper could get access to transportation services easier than in 2005 since the supply of services in 2011 exceeded the demand. With the increasing service development level in Russia and Belarus availability of transport services also improved. Therefore the situation in 2011 was evaluated better than five years ago. The trade balance in the neighbouring countries, e.g. in Poland, Latvia and Estonia, had a positive impact on the availability of capacity, yet in 2011 the countries didn't reach the level of 2005-2006.

According to general assessments, operational quality of transport companies during the period under analysis has improved nearly in all BSR countries. When assessing the operational quality of Lithuanian companies, the majority of respondents stated that it has improved, therefore in the general assessment quality from "neither poor nor good" turned into "good". The change was not significant: according to respondents, only large companies can improve/ensure high quality. Since Lithuania has few large companies, general level of quality has improved slightly.

All respondents noted that situation of operational quality of the international HGV transport in Lithuania and in Estonia, Latvia, Poland improved significantly.

According to the majority of respondents, the estimation of general assessments demonstrated that economic entities were more profitable in 2005-2006 compared at the beginning of 2011. The years 2005-2006 were related to the period of "recovery" and have been successful for the entire transport market: transport demand has increased and companies which managed to meet the demand worked profitably. Here it is necessary to mention Lithuania, since the phenomenon of a growing "bubble" was especially evident in the country: the growing demand determined the increase of capacities by carriers; being able to increase transportation volumes for lower price they received higher profit during a certain period of time. However, as soon as the economic recession began (in 2007) the "bubble" blowed: the demand for transportation decreased and companies were unable to use the capacities. Consequently, profitability has decreased significantly. At the beginning of 2010 obvious signs of "recovery" were observed, therefore the change related to the impact of the above factor is not very high.

With regard to general reduction in the profitability of companies, it was not only due to the economic recession but also to higher prices of energy resources which also increased transportation costs.

When speaking about competitiveness, experts also noted that all companies which experienced recession by distributing funds in a more rational way could be treated as competitive. Therefore by at the beginning of 2011 competitiveness of companies was related to lower transportation costs. According to general assessments, currently Lithuanian and Polish carriers were more advanced, yet Lithuania's competitiveness was based not on small transportation costs but on a favourable geographic location (territory of the country is passed by huge transit flows).

While speaking about competitiveness among companies, experts in Lithuania discerned major competition (both, today and during the period of 2005-2006. It is significant to note that assessment of competitiveness by the representatives of public institutions was nearly the same (i.e. the situation in 2005-2006 and 2011 is very similar), whereas experts representing transport companies evaluated changes in competitiveness drastically (major changes).

Both public authorities and transport associations did not indicate considerable changes with regard to competitiveness in Lithuania.

\section{The Balance between Supply and Demand in the International Road Transport in Lithuania in Autumn}

When evaluating the balance between the supply and demand the experts highlighted that the season of autumn cannot be evaluated unambiguously: during the first period of the season the supply is usually higher; the demand is higher during the second period (pre-holiday period).

The general conclusion could be as follows: the autumn of 2010 was not very successful for the Lithuanian transport market: the majority of respondents highlighted higher supply volumes. 
In view of the above it could be said that the increased consumption determined the demand for transportation services and that supply could not meet the demand. After experiencing the period of recession the transport sector didn't hurry to increase volumes of services, therefore the demand for transportation could not be met. This determined a temporary jump in transportation prices.

When asked to assess the balance between the supply and demand in the international road transport in Lithuania in autumn 2010, the respondents said that transport demand was higher due to the lack of vehicles.

All respondents mentioned that Lithuanian road freight transport fleet fully satisfied Lithuania's import and export service requirements. HGV fleet comprised nearly 22000 vehicles. More than 50 percent of $\mathrm{HGV}$ operated in other EU Member States or transported goods between the EU and Russia. Regarding Lithuanian transport, high competition was due to "cheap" transport in other countries (Belarus, Ukraine). In view of this transport companies had to reduce transportation costs.

\section{The Main Changes in the Market Structure of the International Road Freight Transport in Lithuania during the Past 5 Years}

When evaluating the freight transportation market, respondents highlighted that during the recent five years Lithuania experienced many changes. The most important included:

- high number of bankruptcies: during the crisis the majority of companies had to terminate their activity. According to respondents small companies and economy entities the main part of service package of which consisted of warehousing services, suffered from the recession most of all;

- consolidation: in order to survive during the period of crisis companies were forced to merge and pursue common activity;

- $\quad$ reduced vehicle fleet, i.e. reduction of available capacities (by own will or under compulsion). Some companies had to do this in order to optimise operations, the others because of inability to pay credits;

- reduced sales are related to lower demand and higher transportation costs;

- reduction in the number of employees: during the economic downturn this is a natural phenomenon: in case of the fall in demand (and capacities) it is necessary to optimise operations; therefore the reduction in the number of employees is inevitable.

Other respondents tried to dissociate from the recession and discerned positive changes:

- after elimination of the permit and visa regime transportation procedures to certain countries have been simplified;

- Recovery was observed in 2010: the demand for transportation was increasing, companies increased their capacities.

Respondents highlighted main changes in the market structure for international road freight transport in Lithuania during the recent five years. The number of companies and employees has decreased, majority of them either went bankrupt or merged the international networks (companies). Several companies acquired DSV, consolidated logistics services and could offer a wide spectrum of services (signs of 3 PL business). Considerable reduction in the number of forwarders has been observed. High number of transport companies experiencing real of fake bankruptcy. These factors were determined by changing customer's needs. The focus was given to CIS countries. It was necessary to increase the speed of services directed toward transit flows. There were also multiple political and economical reasons: changing export and import markets and transportation trends included the changes in the customs tariffs and attitudes.

In summary, it could be stated that main changes in the market structure for international road freight transportation in Lithuania during the recent five years were: high number of bankrupt transport companies in 2009 (about 20 percent), big number of unpaid and returned (to credit institutions) freight vehicles. During the pre-crisis period transport companies employed about 80000 employees. During the downturn this number has decreased and now it has been again increasing. Today the market has less weak and small companies and large transport companies have improved their operations. The role of forwarders has also increased because of a smaller size of goods consignments. This resulted in a more frequent transportation of partial freight and consolidation of services. 
Changes identified by respondents:

- Essential liquidations and bankruptcies of the small companies;

- Lack of HGV drivers in own country;

- Some companies established their subsidiaries in the Kaliningrad district; this helped to solve the problem of permits to Russia;

- Foreign transport companies didn't appear in Lithuania;

- Transport fleet underwent significant improvements. Near 30 percent of HGV have Euro 4 and Euro 5 certificates.

According to respondents the main factors which determined the changes are as follows:

- Global economic downturn;

- Lack of permits to Russia since main international transport flows are between Western Europe and Eastern Europe (Russia, Belarus);

- Smuggling (invoice counterfeiting when transported cargo and cargo in the documentation differed). This determined more frequent checks by relevant services (time and other costs have also increased).

Other reasons included:

- Strong influence of the financial crisis;

- Pressure by the international transport market.

\section{Conclusions}

Operational quality of companies during the period under analysis has improved in Lithuania and nearly in all BSR countries.

Transport companies worked more profitably in 2005-2006 compared to the end of 2010; after "overcoming" the crisis they didn't manage to reach the initial level; besides lower profitability was also determined by growing prices of energy resources which increased transportation costs.

By the end of 2010 competitiveness of companies was related to lower transportation costs and high quality.

During the recent years many changes occurred in freight transport market, but the most significant are: increased number of transport company bankruptcies and reduced vehicle fleet. The market during the above period both expanded and shrunk (natural selection - only the strongest survived). This was determined by the economic factors (global recession).

The current market conditions have positive impact on the Lithuanian freight transport market: the volumes of export, import and transit flows are increasing; the vehicle fleet also expanded.

\section{References}

1. University of Turku. (2011). Compliance and enforcement of regulations of international road haulage. Turku, Finland: University of Turku. 103 p. ISBN 978-952-249- 084-1.

2. Bazaras, D., Palšaitis, R. (2011). The Impact of the Market Structure on Safety and security in the BSR: Lithuania Point of View. In Proceedings of the $11^{\text {th }}$ Conference on Reliability and Statistics in Transportation and Communication, 2011, (RelStat'11) (pp. 173-175). Riga, Latvia: TTI. ISBN 978-9984-818-46-7.

3. Bazaras, D., Palšaitis, R., Solakivi, R. (2007). Experts Interviews in Lithuania (57 p.). Turku, Finland: Turku School of Economics.

4. Bazaras, D., Palsaitis, R. (2009). Estimation of Logistics Situation Changes 2007-2009 in Lithuania. Transportation and Telecommunications, 10(2), 4 -9.

5. Palšaitis, R., Bazaras, D. (2012). Market structure analysis for international road freight transport in Lithuania: C.A.S.H. reports, 6 (128 p.). ISBN 978-952-249-093. 